\title{
UNAS PALABRAS PARA ELENA ENTREVISTA A ÁLVARO MUTIS
}

\author{
ÁLVARO MUTIS
}

R.- ¿Con qué adjetivo calificaría a Elena Poniatowska?

A.M.- Una mujer excepcional.

R.- ¿Cuándo la conoció?

A.M.- Conocía Elena Poniatowska en la Galería de Antonio Sousa, un galerista muy importante (que ya no nos acompaña) que tuvo una galería de pintura contemporánea. Era una exposición y al mismo tiempo un centro de conversación y de encuentro muy grato. Yo había trabajado en Colombia, durante dos años, en la embajada de Polonia, en el Departamento de Información, durante la guerra, y me enamoré de ese país, de sus escritores y músicos. Fue un placer enorme conocer a alguien descendiente del rey de Polonia, su ilustre abuelo.

R.- Cómo calificaría a E. Poniatowska como persona y como amiga.

A.M.- Como amiga fue para mí una bendición, porque estuve 16 meses en la cárcel aquí en México: el gobierno dictatorial del militar Rojas Pinilla, había pedido mi extradición. Elena me iba a visitar con frecuencia. Ya nos habíamos conocido en la Galería de Antonio Sousa, y fue una amiga extraordinaria. En esa situación, la compañía y la solidaridad es, realmente, muy necesaria. Desde ese momento se creó una amistad inolvidable.

R.- Ella defendió su causa, a través del periodismo.

A.M.- No, mi causa no era defendible. Suponía crear problemas con la embajada de Colombia y yo prefería que no se hiciera. Sí, escribió mí, sobre mi obra y mi poesía pero sobre el asunto que me tenía preso no. Por fortuna.

R.- ¿En aquel momento era usted muy conocido en México?
A.M.- No, no, llevaba apenas un año viviendo en México. Vine para refugiarme. Un amigo me avisó: «Mira, el general Rojas Pinilla va a hacerte un juicio, tienes que irte», y me fui al dia siguiente, y me vine a México.

R.- ¿Ella contribuyó a dar a conocer su situación?

A.M.- Sí, sí, desde luego.

R.- ¿Qué opina de Elena como escritora?

A.M.- Es un conjunto de apreciaciones. Pero lo que me sorprende, lo que me encanta de Elena es su energía constante. Es una especie de pila eléctrica. No escribe por escribir, ni se detiene en temas superfluos ni vanos, va al fondo de los problemas, con una responsabilidad y un criterio y una lucidez realmente magníficos.

R.- ¿Qué libro o qué obras destacaría?

A.M.- Me pasa una cosa muy curiosa, no se me ocurre destacar ninguna. Cada una tiene su propia luz. Es la energía vital y la lucidez que se hacen presentes, en cualquier libro. Reflejo de su propia vitalidad.

R.- ¿Qué opina de "Amanecer en el Zocalo»?

A.M.- Está muy bien. Dice cosas que en México no suelen hacerse públicas, y las dice con una gran lucidez, y con una gran responsabilidad. Ese libro es ejemplar y muy necesario en este momento para el país.

R.- Como escritor, ¿cómo ve el futuro de esa literatura testimonial?

A.M.- Bien, muy bien. Tenga en cuenta que hay una tradición en Europa de esa literatura. Los textos de los escritores que recogieron la voz del pueblo durante la Revolución Francesa hoy día son clásicos.

R.- ¿En México cree que va a haber una continuidad?

\section{Álvaro Mutis}

Álvaro Mutis, poeta y novelista, nacido en Bogotá, ha sido director de revistas muy diversas. Amigo de autores como García Márquez, Luis Buñuel, Octavio Paz, Carlos Fuentes o Elena Poniatowska, ha residido habitualmente en México, donde llegó como exiliado. Internado en la cárcel de Lecumberri, escribió una obra teatral sobre uno de los presos, El Cochambres, y la obra El diario de Lecumberri. Entre sus obras poéticas iniciales destacan Los elementos del desastre (1953) o Los trabajos perdidos (1963), a la que sigue Summa de Maqroll el Gaviero (1973). Entre su obra destaca también el periodismo, como su columna «Bitácora del reaccionario» (1977), o el libro de poemas Caravansary (1981). Muchas de estas obras se recopilan en Poesía y prosa (1982). Nuevas producciones son sus poemarios: Los emisarios (1983), Crónica regia y alabanza del reino (1985), Un homenaje y siete nocturnos (1986). La figura de Maqroll el Gaviero inicia su andadura en la novela con La nieve del almirante (1986), y continúa con Ilona llega con la lluvia (1988), Un bel morir (1989), La última escala del Tramp Steamer (1989), Amirbar (1990), Abdul Bashur, soñador de navios (1991) y Tríptico de mar y tierra, integrados en Empresas y tribulaciones de Maqroll el Gaviero (1993), y la recopilación Caminos y encuentros de Maqroll el Gaviero (2001). Ha ganado el Premio Príncipe de Asturias (1997), el Premio Grinzane Cavour (1998) y el Premio Cervantes (2002).
Unas palabras para Elena Entrevista a Álvaro Mutis Álvaro Mutis 


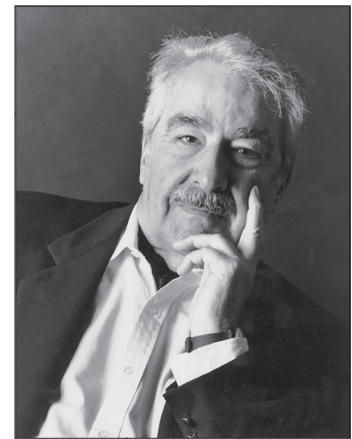

Álvaro Mutis.
A.M.- Desde luego, esos libros de Elena quedan como un testimonio deslumbrante del México que ella vivió. El tiempo no actuará contra esos libros. Serán siempre libros vivos.

R.- Qué cree que ha innovado más Elena, en el terreno del periodismo por su atrevimiento, por las preguntas y los interrogantes en la sociedad mexicana, o ha abierto un camino más en el terreno literario.

A.M.- En los dos. En los dos. Ella escribe en forma paralela siendo un testigo de su tiempo y a la vez creando un mundo de ficción que es tan real como el otro.

R.- Respecto a esa relación que ha mantenido con las letras mexicanas, ¿ cómo ha sido la relación con Elena y, por otro lado, con las letras mexicanas que rodeaban su vez a Elena?

A.M.- Elena ha sido una persona muy independiente, sí ha tenido contacto con los demás escritores, pero ella es ella. Yo he tenido... tuve amistad muy, muy cercana $-\mathrm{y}$ me lleno de gratitud al solo pensar en él- con Octavio Paz. Lo conocí a los pocos días de llegar a México y conocí también a Carlos Fuentes y a través de ellos conocí a muchos otros escritores y siempre he tenido una relación con ellos muy, muy cordial.

Respecto al modo de hacerlo, Elena ha escrito sobre todos estos escritores y siempre ha escrito como es ella, no inventa, siempre ha reflejado su verdad, recuerda y constata lo que recuerda.

R.- Aparte de Elena, sus relaciones, entonces, serian más con Fuentes y con Paz, dentro de la literatura.

A.M.- Sí, con Paz fue muy positiva porque me acompañó en esta gran dificultad, y en esos meses de prisión, fue constante, estuvo presente conmigo y Carlos también.

Tuve una gran acogida en el ámbito literario de México.

Yo no puedo conformarme con la ausencia de Octavio. No está ausente, lo tengo presente a diario. Escribió sobre México un libro de una lucidez absoluta que es el Laberinto de la Soledad. Allí está México.

R.- ¿Serían complementarias la visión del Mexico de Elena con la visión del Mexico de Paz?
A.M.- No, no. Son distintas las dos, muy auténticas las dos, muy razonadas las dos, pero son completamente distintas

R.- ¿En qué radicaría esta diferencia?

A.M.- En el caso de Octavio el hizo una inmersión en su más profundo ser, buscando el México que llevaba adentro y que él conocía.

En el caso de Elena, es una visión muy clara, pero hay más interés en la vida diaria, que también son la misma vida mexicana, y reflejan la misma vida mexicana, pero por otro camino.

R.- Me bubiera gustado continuar la entrevista, pero como le dije, solo iban a ser diez minutos, no quería robarle más tiempo.

A.M.- Ah, sí, pues nos veremos en Madrid.

R.- ¿Cuándo va?

A.M.- Me dieron el premio Rosalía de Castro. Voy a Santiago, que es una región que adoro. Soy un gran lector de Alvaro Cunquiero...

Esta mujer, Rosalia de Castro, es increíble. Piense en una mujer: hija natural de un abad de Padrón y de una señora de alta sociedad. Hasta los 15 años vive con las hermanas de su papá. Después se va a vivir con su mamá, se casa, empieza a escribir: su marido apoya mucho su vocación y su producción. Tiene siete hijos, todos mueren, uno detrás del otro. ¡Y ella muere a los 47 años! Y esa vida la ve usted en su poesía. Pero al mismo tiempo se presiente su amor por el paisaje, la inmersión en el paisaje... Las aves, las flores, las frutas, los animales, los caminos, los ríos, eso la salva, le permite servir viviendo. A mí me tiene traspasado esa mujer...

R.- Es cierto. Tenemos que continuar esta conversación en España. Entonces, ¿cuándo podemos vernos?

A.M.- En septiembre o en octubre, porque estoy recibiendo un grupo de marinos retirados que han creado un premio, Nostromo, la novela de J. Conrad y quieren que yo vaya a entregar los premios. A lo mejor me encuentro con Maqroll el Gaviero.

Ya me gustaría... 